ROCZNIKI TEOLOGICZNE

Volume LXV, issue 9 - 2018

English version

DOI: http://dx.doi.org/10.18290/rt.2018.65.9-10en

\author{
REV. PAWEŁ TAMBOR
}

\title{
SELECTED ASPECTS OF THE RELATIONSHIP BETWEEN THEOLOGY AND THE NATURAL SCIENCES
}

\begin{abstract}
The article is an elaboration and a critique of certain aspects of the discussion on the relationship between theology and the natural sciences, with special consideration given to the methodological level. In the paper, I will show that in the domain of the natural sciences, there is a crucial and substantial evolution of methodology in terms of the scientific explanation, theories of truth, methods for justifying scientific hypotheses, etc. I will point out the specific loci where theology can effectively meet science, conserving, however, its autonomy and specificity. Modern cosmology is presented as a special case study in this discussion.
\end{abstract}

Keywords: theology; science; methodology; cosmology.

The scope of issues that fundamental theology deals with is quite broad. The most important issues are mention by Henryk Seweryniak (Seweryniak 1993): its possibilities, the objective and formal scope of Christian apologetics, justifying the credibility of Christianity, and reflecting on the essence of the Christian faith. In this context, fundamental theology is a field that uses conceptual and speculative tools to explain what Christianity is and justifies conceptual structures to support its claims. In the context of attempts to establish its status as a methodological discipline, the author clarifies: "In this understanding, fundamental theology is a theological discipline that is rational, open to the culture of its time and deals with the credibility of God's salvific revelation through Jesus Christ and his presence in the Church as a mystery and community" (Seweryniak 1993, 10).

Rev. Dr. Paweł Tambor is an assistant at the Chair of Christology and Ecclesiology in the Institute of Fundamental Theology of the Faculty of Theology at the Catholic University of Lublin and the rector of the Priestly Formation Semiary in Kielce; mailing address: ul. Jana Pawła II 7, 25-025 Kielce; e-mail: pawel.tambor@kul.lublin.pl 
We must point out that fundamental theology is distinct from widely understood apologetics and now has greater precision in the types of issues it deals with: the historicity of Christianity, the perception of revealed contents both on an individual and ecclesial dimension, and Christological problems (primarily the historicality of Jesus Christ and the contents of divine revelation in Jesus). The characteristic formal subject of fundamental theology usually includes the concept of credibility, whose universality is justified by applying rational and critical tools.

Over the years, the interdisciplinary issue has been discussed concerning the methodology of science (Walczak 2016). On the one hand, the distinctiveness of scientific disciplines is exposed on various levels, and on the other hand, such areas are sought in the relationships between the sciences, which must necessarily be worked out by scientific disciplines that differ from each other. Marian Rusecki indicates that the particularly legitimate place for interdisciplinarity in the context of fundamental theology are the so-called borderline problems (Rusecki 1994). He points out that fundamental theology is simply called "a borderline discipline."

Worth pointing out are the moments in the methodology of fundamental theology where it is particularly easy to identify meeting points with the natural sciences. M. Rusecki gave a whole list of possible goals and tasks for fundamental theology: "[...] to defend the faith, the need to rationally justify the faith, the need to justify the supernatural nature of Christianity, the need to develop basic concepts for theology, to practice metatheology, prepare man to accept the faith, show the meaning of life, explain the relationship between reason and faith, and carry out dialogue with unbelievers" (Rusecki 1994, I:83-84). A primary goal of fundamental theology and a kind of common denominator of these many tasks is justifying the credibility of Revelation. This is its unique objective goal. Moving on, we can attempt to justify this very justification (i.e. answer the question: "why justify?"); so why should we take on this task of justifying the credibility of the contents of Christian revelation at all?

In response, we can give such reasons as: "to bring man to the act of faith, to awaken our openness to the faith." Credibility is, among others, the possibility of getting to know and grasping such truths of the faith that they will be expressed in available epistemic categories. M. Rusecki, presenting various concepts of credibility (sign, personalistic, based on testimony, subjective transcendental), points out that understanding credibility is subject to continuous dynamics along with the development of the sciences. This justifies 
the attempt undertaken in this article. One of the most interesting attempts in this context is the issue related to the goal of the process of justifying the credibility of Revelation. In the epistemological sense, this means reaching a state of obvious credibility, and such a state would be considered ideal. Of course, we can set some epistemological ideals, whereby the act of faith becomes "earlier." We deal with a similar situation in the empirical sciences, using the so-called approximate version of the classical definition of truth.

Marian Rusecki characterizes the methodological specificity of the natural sciences in the following way: "To practice the physical sciences, it is enough to know the methods used. At the same time, insight into the nature of the sciences themselves is not required. From this comes the conclusion that the natural sciences are non-reflective. Physical sciences are learned not by reflecting on them, but by actually practicing them" (Rusecki 1994, I:32). This seems to be a somewhat simplistic view, which reduces practicing the natural sciences to simply performing calculations and conducting and recording observations.

Regarding the natural sciences, there is constant reflection on the status of not just the methods (the meta-subject level), but also the dynamics of the development of the methodology itself (the meta-meta subject level). Certainly, the place for meta-subjective reflections in physics, biology or chemistry is much more limited than in the philosophical and theological sciences. The textbooks for physics or other natural sciences express this image quite well. They convey the current state of knowledge about theories that are considered to be valid, while the part devoted to history, for example in physics, has a very limited content and often functions as a curiosity. Yet in theology and philosophy, studying their history is predominant.

Analyzes carried out in this paper are not so much an exhaustive presentation of fundamental theology's methodological status, but rather an attempt to identify the issues that may prove particularly important in relation to the "world" of natural sciences, both at the methodological and subjective levels. Our analysis will be carried out from the point of view of methodology and, broadly speaking, the philosophy of science, with particular emphasis on selected issues from contemporary cosmology. Theologians sometimes put these issues into the so-called second group of thematic fundamental theology: "searching for the theological implications of the results of the exact sciences [...]" (Seweryniak 1993, 11).

In the typology of dialogue proposed by Andrzej Anderwald, the presented position could be classified as a weak type of synthesis (Anderwald 
2007, 223-225). Particularly important in the context of the contents presented are some parts of the so-called metaphysical argument on the credibility of divine revelation, and in particular the thesis: "In the light of Revelation, all of the temporal and spatial reality, such as a religious sign, point to the transcendental plane as being original and final at the same time [...]" (Kaucha 2013, 59).

At the start, the following formal and contents remarks are necessary. The terms "science" or "scientific" used in the article extend beyond the natural sciences (research according to the scientific method). That is, both theology and philosophy (metaphysics, epistemology, etc.) are considered to be scientific disciplines, although they are not, of course, sciences in the sense of science. I do not consider the methodology of the natural sciences as a model (paradigmatic) for theological or philosophical sciences. When writing a work from the point of view of the philosophy of natural sciences, I aim not to teach the theologian how to cultivate my field, but point to the methodological "phenomena" and "units" in the natural sciences which may be the subject of interdisciplinary debates between theology and the natural sciences. I do not propose an exhaustive model of the science vs. faith relationship, but I draw conclusions from the evolving methodology of the natural sciences, which I find to be interesting for a theologian.

In the first part of the work, I present a conceptual panorama of the relationship between theology and the natural sciences. In the second part, I analyze several selected issues from the methodology of the natural sciences (rationality / credibility, falsification as the demarcation criterion and explanatory function in science) and indicate in what way they can be the basis for an interdisciplinary discussion with theology.

\section{ABOUT THE NATURE OF THE RELATIONSHIP BETWEEN FAITH, THEOLOGY AND THE NATURAL SCIENCES}

The relationship between the natural sciences and theology is characterized or defined at a high level of generality in different ways. A rather popular approach, for example, uses the abbreviations NOMA (non-overlapping magisteria) and POMA (partially-overlapping magisteria). This is held by positions, respectively dissconcordism and concordism, that are overly negative (since it is assumed that theology and the natural sciences are in some opposition to each other), or too positive (often in a methodologically inaccessible 
way we try to mix theological and scientific conclusions) (Lambert 2018). I am of the opinion that these attempts are so general and extreme that they give rise to much confusion in the discourse on the subject of the relations between various sources of knowledge: the religious, revelatory and empirical; different conceptual schemes and languages; different types of explanations provided by theology and the natural sciences.

To avoid this, it is necessary to identify and point out the concepts in the natural sciences and theology which should not be equated (such as the metaphysical and creationist origins of the world with the Big Bang theory, metaphysical nothingness with a physical vacuum), and those where some kind of relationship is permissible. Hans-Dieter Mutschler warns us against undertaking similar attempts to directly connect physics with theology, which threaten to "naturalize the spiritual world and overload theology with the natural world" (Mutschler 2007, 193). Interestingly, on the other hand, Karl Rahner admits to common places of discussion between theology and science despite different methodologies: "Catholic theology, unlike some tendencies in Protestant theology, cannot a priori express the view that, despite a different methodological assignment, the area of its interests does not have any points of contact with a bit of reality from the very beginning in the research studies of theology, and thus there is no possibility of a mutual conflict" (Rahner 2007, 2:63).

Dominique Lambert proposes three methodological principles in the given discourse: 1) "I reject the idea that a sufficiently sanctioned scientific truth (for example, the theory of evolution) abolishes dogmatic contents and vice versa;" 2) "the science vs. theology dialogue, by no means unnecessary, is basically possible and proves necessary for both science and theology. I therefore reject fideism, which limits faith to the field with no access to the truths of reason in general or to the truths of the natural sciences in particular, and rationalism, which would argue that faith is an obstacle in discovering the truth;" 3) "[...] relations between science and theology cannot be analyzed according to the perspective that places scientific activity, as a fullfledged human activity, beyond the reach of ethical issues" (Lambert 2018, 921). In his analysis, he convincingly suggests and justifies the areas of interest to both science and theology that are suitable for creating a meeting place on three levels: ontological, epistemological and ethical.

The separate scientific method is due to the natural hierarchy of the levels of description, which aims to reduce, for example, the laws of physics to their most fundamental state. Science, however, does not provide a sufficient 
description of the whole reality, since such categories as the meaning of the world and man, the purpose of creation, and the ethical implications of the development of science itself defy it. The natural sciences, however, remain autonomous in their domain of describing and explaning the physical, chemical or biological aspects of the reality under investigation. On the other hand, theology determines the nature of the relationship between God and the world, and in this sense it is helpful for science, explaining what the biblical demythology of nature is based on, and in what way it somewhat frees the scientific method, specifying the meaning of the act of creation, placing it primarily in the metaphysical order, and explains the nature of the causal relationship between God and the world (Ratzinger 2001, 25-26).

Cosmology, in particular, is the area in which the tension between theology, particularly fundamental theology and the natural sciences, is perhaps most emphasized. This is because it asks questions about the whole universe. Cosmology, when questioning the universe, is special on the one hand because it investigates everything that exists in the physical sense as a single object. On the other hand, it is also general, because it claims a certain right to statements regarding the entire universe; it allows speculations based on postulated cosmological principles. In addition, cosmology is interested in both the beginning and the end of everything physical. There is a methodologically forced asymmetry here in favor of retrognosis (predicting about the past). Hence, cosmologists are sometimes called prophets of their own past, which somewhat abuses biblical categories. This is because the light of distant astronomical objects reaching us comes from the past. Cosmological models are designed primarily to reconstruct the past history of the universe, and only then can we make predictions.

Placing a reconstruction of the delicate relation between theology and science in the solid context of ontology, epistemology and ethics is a very appropriate approach. It allows us to highlight the traps of both concordism and discordism. Concordism may lead to various forms of pantheistically treating the relationship between God and the physical world to errors in explanations that reduce God merely to being the natural cause (which is often expressed by the phrase "God is needed to cover up holes in our knowledge"), including a deistic approach refusing to grant God any relationship with the world outside of the creative act. On the basis of epistemology, however, concordism may lead to a specific identification of knowledge on the most fundamental theories unifying these interactions with God's ideas, thus treating the process of acquiring knowledge in the natural 
sciences as an even better way to know God than theology, which is based on revelation or giving theological interpretations for deterministic or chaotic systems.

Disconcordism, in turn, while absolutizing the autonomy and separateness of theology and the natural sciences, does not allow for any challenging explanation of reality, and in particular about man who has a dual, yet coherent nature mutually interacting with the physical and spiritual. It is clear that in the context of justification, theology and the natural sciences are treated separately, while the very history of science shows that both disciplines have something to say. The very search for physical laws in the natural world is somehow derivative thinking about Him who is the Legislator or causa causarum. Placing the category of truth into the scientific discourse, at least as a certain regulative idea, means accepting the possibility of knowing the world and the very pursuit of truth as a rational strategy.

Dominique Lambert, having criticized concordism and disconcordism, proposes a position bringing about a type of coherence. The coherence is possible, for example, when complementing the physical explanation of the existence of the universe (with so many dimensions, such and not other fundamental and lasting values as observed traits) with a metaphysical and theological explanation referring to God. At the epistemological level, this coherence will concern keeping the category of interpretation and meaning on the side of the natural sciences, and the category of sense on the side of theology. In the field of cosmology, for example, speculations about the meaning and interpretation of the so-called anthropic conclusions are still being carried out. Certainly, the existence of intelligent beings, life based on a carbon compound biology, requires a particular coincidence of events, ranging from the values of physical constants, properties and relations within the solar system to the age of the universe. On the other hand, science will have problems with determining the modal nature of these relationships. Yet, theology provides a hermeneutic argument that uses the notions of the meaning and purpose of creation (McGrath 1999, 247).

\section{THEOLOGY AND NATURAL SCIENCE IN A METHODOLOGICAL DIALOGUE}

The methodological uniqueness of theology as compared to the sciences, including philosophy, is based on the specifics of the sources of theology as 
such, which are God's revelation and obedience to the faith. Theology is therefore a kind of intellectual study, whose primary source are the so-called truths of revelation. On the other hand, theology uses tools from the workshops of other types of sciences (sociology, linguistics, archeology, history, etc.). The interdisciplinary nature of theology results from both its internal character and the external specificity of scientific and didactic procedures, which do not specifically distinguish theology from other ways of practicing science. Tomasz Węcławski, characterizing the specificity and identity of theology as such, indicates that it deals with the subjective research, analysis and presentation of the relationship between what is Divine and what is part of the created world (Węcławski 2005). Let us point to certain types of issues that are fundamental in the discussion on the status of theology, particularly fundamental theology.

\subsection{THE RATIONALITY AND RELIABILITY OF TEOLOGY AND THE EMPIRICAL SCIENCES}

The first point is the question of rationality. Sometimes it is said that theology is a scientific discipline that somewhat borderlines with rationality. Many discussions about faith in general and theology as an intellectual reflection on the contents of faith concern allegations in relation to rationality. The most frequently mentioned criteria or carriers of rationality in science (particularly scientific studies) are: the quality of scientific language, which has the feature of being precise, meaningfulness, the ability of claims to undergo empirical verification, the non-contradiction of scientific theories, and methodology. Monika Walczak points out that in antiquity, rationality as a feature of the scientific approach to the world was related to a departure from magical and sacred explanations of the world, now leading to searching for explanations in the world itself (discussion on arche) (Walczak, 2006). The classical ancient concept of knowledge uses criteria that can be considered to be determinants of its rationality: knowledge is rational, justified and true belief. The ideal of rational knowledge are mathematical beliefs. Aristotle extends this mathematical ideal knowledge to be certain and necessary for probable beliefs, which are a meta-subject feature of practical knowledge.

The so-called classical rationalism places its concept of rationality in the domain of deductive knowledge, where statements in the system of knowledge are derived from a limited number of premises. Cognitive cognition according 
to this concept exceeds empirical cognition and any cognition that is based on other than a priori based indisputable beliefs using the principles of noncontradiction, identity and sufficient reason. Seventeenth-century classical empiricism, on the one hand, considered sensory experiences to be the only source of valuable knowledge. Sensory experience provides so-called simple ideas, which are then subjected to intellectual processing in the processes of idealization and abstraction, as a result of which complex ideas are formed. On the other hand, based on sensory experience, attempts to acquire general knowledge in the induction process are inherently uncertain (see the so-called Hume's problem). A philosophy of learning based on the modern works of Newton, Galileo or Bacon dealt with a specific combination of both trends. Knowledge using deductive mathematical tools, however, found the necessary empirical empowerment and justification in sensory experiences. On the one hand, the starting point for Newton was the famous "I do not state hypotheses," and on the other hand, the method of practicing science can be called inductive-deductive.

The accusation of irrationality in relation to theology is connected with the acceptance of God and divine matters as a special subject of our reflections. Thus, the source of theology goes beyond what is rational to human beings, it allows the intellectual examination of an object which inherently needs the broader understanding of rationality. Defending the rationality of theology can go in several directions. In general, theology is placed in the intellectual conceptual framework of a certain metaphysics, and therefore, it is possible to verify its claims in this context. For example, the so-called arguments for the existence of God as part of realistic metaphysics are constructed in this way.

A modern example of a study on the relationship between God and the world, which can be seen as being based on the metaphysics of God in classical theism, is the book by Dariusz Łukasiewicz (Łukasiewicz 2014). Next, the events concerning Jesus Christ, his birth, life, death and resurrection are considered verifying in an empirical sense. In particular, rationalists can be defended by analyzing God's relationship with the world, both at the moment of creation and in sustaining its existence (Anderwald 2007, chapter 2). It turns out that we can rationally argue for the convergence of essential results, for example, empirical and theological teachings about the origin of the universe, of course, keeping the necessary reservations about the differences between the metaphysical and natural character of argumentation and the different ontic status about what the beginning is. 
The study by rationalists, including their private convictions, will be difficult or predestined to fail for theology if we want to directly transfer the methodological categories from the natural sciences to the area of theology. The natural bridge is provided by philosophy (e.g. natural philosophy). ${ }^{1} \mathrm{We}$ must note, for example, the positions regarding the epistemology of the nature of scientific knowledge: a) fundamentalism, where knowledge consists of two elements: basic statements (not subject to justifications) and non-substantive statements that are justified on the basis of the former; b) coherentism claims that knowledge does not have a hierarchical structure, and the justification process takes place within the structures between statements; c) internalism is the justification of statements in the corpus of knowledge made using the internal conditions of the cognizing person; d) externalism is when the justification needs to refer to the cognizer's external elements; e) reliabilism's belief is justified if it is the result of a credible process (credibility is measured, for example, by the number of real beliefs obtained in this process).

In fact, for each of these positions, in the framework of fundamental theology's methodology, it is possible to point out objective or formal references. Therefore, we can justify the rationality of beliefs regarding the faith in theological discourse from the point of view of a hierarchical structure based on statements that would generally be considered on the basis of theology, that is, based on the principle of certain obvious points of faith. Second, the criterion of contents coherence has an essential application, for example in assessing the results of the work of theologians and the experiences of mystics in confronting the Magisterium. The criterion of content compliance can be understood as the requirement of internal consistency of religious beliefs that form the doctrinal system of a given religion. However, it is also possible to refer to certain forms of authority in the methodology of the natural sciences. Sometimes, in the awareness of scholars (particularly representing theology or philosophy), there is an idealized view of the natural sciences, which is expressed in the idea that science is not based on authorities.

In the classical context of the process of justifying scientific statements, this is true. However, for example in physics or cosmology, we often deal with the so-called degeneration problem. This happens when many competing hypotheses explain the phenomenon to a similar degree. In such situations,

\footnotetext{
${ }^{1}$ Some authors in particular point to natural philosophy as the most adequate "bridge" linking the natural sciences and theology (Lemańska 2010; Heller 2014; Hajduk 2004).
} 
the criterion of compatibility among the scholars is used, which recognizes that a certain theoretical model can be considered as the standard one in the current state of knowledge. This is the case with the so-called standard cosmological model. The general consent of scholars is the criterion that can be considered to be a form of appeal to authority. Third, the faith experience requires taking into account the subjective conditions of scientific cognition in theology: theological cognition (e.g. by C. Rahner), as well as the experience of the community of God's people, is historical in the full sense of the word. Epistemological reliability seems adequate in attempts to reconstruct the process of the faith's continuity and its message. Naturally, theology uses its own conceptual scheme and refers to the right sources, but it is very instructive for the methodologist to try to explain the rational nature of theology using common criteria for other branches of knowledge.

\subsection{FALSIFIABILITY: THE EVOLUTION OF THE DEMARKATION CRITERION}

The criterion of falsifiability seems to be most controversial in the context of theological sciences, because it was intended to demarcate the empirical sciences (what science is and what it is not in the sense of scientific research). This is worth discussing, considering the important methodological evolution of the concept of falsifiability even for Karl R. Popper himself, who was its main advocate. Necessary modifications of the falsifiability criterion have become indispensable mainly due to the fact that in the field of natural science, we are also dealing with a certain type of speculation. An example is cosmology, which claims the right to statements about the universe as a whole (beyond the epistemic horizon) and thus becomes an example of speculation according to the ideas of deductive hypothetism. ${ }^{2}$

The modern methodology of natural science exposes the tools of scientific discovery and at the same time the goal of science, which is the verification of scientific hypotheses. This verification is carried out in two ways: by confirming hypotheses or their falsification. The contemporary debate on the value of the induction method has been going on since the times of D. Hume, who showed that many hypotheses are equivalent to each other, and therefore their confirmation by empirical data will never be made with

\footnotetext{
${ }^{2}$ An example of such analyses is the following book published in Polish: (Kragh 2015).
} 
complete certainty. Examples of the historical application of the induction method were Kepler's generalizations of Tycho de Brahe's careful observations; Newton's discovery of the law of gravity as a result of the inductive generalization of Kepler's "phenomena" of planetary movements; or Ampere's discovery of electrodynamic laws by the inductive generalization of his observations of electrical currents. This points to the basic weakness of inductionism, which consists in the fact that it is unable to explain why these and not other facts were chosen as a starting point by way of formulating general statements.

This methodology, referred to as hypothetism or deductionism, proposes a radically different reconstruction of scientific processes: scientific hypotheses are tested in such a way that their deductively derived consequences are subjected to empirical testing. In the discussion on the scientificity of various disciplines, including theology, it must first be stated that the so-called dogmatic falsificationism was a fiasco. It claims that the empirical basis for the falsification of the theory is infallible, meaning that the criterion of falsification leads us to proven knowledge. We can agree with this conclusion if the truth remains as a certain limit in the cognitive process, being a regulative idea. As Adam Chmielewski notes: "The aim of learning is to acquire real knowledge. Although truth belongs to the field of the idea of regulative, ideal, unrealizable standards or postulates of an almost moral character, it is within our capabilities to improve and develop knowledge, meaning approach the truth" (Chmielewski 1995, 67). ${ }^{3}$

In this context, for theology, of particular importance first of all is the very fact of the existence of truth as an idea determining scientific activity, and second, that it is a mere regulatory idea (Popper points out that science is a kind of endless game or adventure). Adam Olszewski, enumerating and characterizing the loci where theology meets science, discusses the category of truth. He gives very interesting arguments that it is not so much accepting the double theory of truth, somewhat different for theology and science, but rather points to the possibility of two truth theories: correspondence and coherence on the basis of theology (Olszewski 2015, 100-101).

Naturally, in theology, truth is a category that is ontic rather than epistemic. Truth is a Person. The analysis of the concept of truth according to the methodology of the natural sciences as an epistemic regulatory idea is

\footnotetext{
${ }^{3}$ Józef Życiński presents a broader discussion on the ties between rationality and the approximate theory of truth in science (Życiński 2015, 147-160).
} 
important for the theologian, not because he is supposed to adapt it to his methodology, but for several other important reasons. First, he learns that empirical teachings are "simply" seeking the truth, and so Truth itself should be sought elsewhere. Second, the very striving for the truth present in science and questions about the truth rooted in the cognitive structure of man can be used as an argument in theological discussions.

Mature falsificationism, which resigns from the concept of simple falsification, and expands the concept of corroboration and consequently the rivalry between many competing hypotheses, introduces us to a certain point of view of the methodological "world" of Bayesian methods. Let us first distinguish between two issues: the Bayesian methodology and Bayesianism as a normative or descriptive philosophy. The starting point of Bayesian methodology, which is applicable in modern cosmology (Hobson 2010), economics, psychology, as well as theology (Swinburne 2004), is not a question about the validity of scientific hypotheses, but an answer to the question of whether a given model is better than the others in the light of data. We expect the sun to rise tomorrow not because it has always been rising to this day, but on the basis of our models concerning the structure and dynamics of the movement of astronomical objects.

There are also interesting attempts to reformulate the criterion of falsifiability with reference to procedures and explanatory hypotheses in the natural sciences (in this case cosmology), such as anthropic reasoning and the category of the multiverse. In particular, the latter proposal is commonly accused of being non-scientific and is understood as a derivative of non-falsifiability. Cosmologist S. Carroll criticizes the criterion of falsifiability in the case of subtle physical theories in which empirical consequences ${ }^{4}$ are very carefully constructed or when we do not have the ability to observe the possibility of testing them. In this context, it reforms the falsifiability criterion, pointing to two other features of a theory that is considered to be scientific: a theory should be defined and empirical. A defined (finite) theory should contain some unambiguous claims about reality. An empirical theory does not mean that it is suitable for formulating testable / falsifiable predictions. We notice the empirical side of a theory by the way it handles empirical data. Therefore, even ontological assumptions that we make within a theory's

\footnotetext{
${ }^{4} \mathrm{Cf}$. the discussion in the www.edge.org webpage on the topic "What scientific idea is ready for retirement?": https://www.edge.org/response-detail/25322. H. Kragh also writes on the need to correct the criticism of the criteria of falsification in Popper's classical sense (Kragh 2015).
} 
framework do not have to be testable, yet including them in the process of inference (explanation) significantly affects its effectiveness.

According to Caroll, a researcher, on the basis of a certain speculation, may therefore, according to his practice, introduce ideas and non-falsifiable concepts and postulate their existence (in this case one of the concepts of the multiverse) to assess the value of empirical records in the light of this assumption. Of course, the thesis "God exists" is not falsifiable in the world of empirical science, but it influences how we interpret these data in certain contexts. Let's recall that the so-called path of St. Thomas, the arguments for the existence of God, come from observing the world: they are a posteriori. God, therefore, is not treated as a competing explanation for the natural sciences (if this were the case, we would make the mistake of "God of the gaps"), but as a completely different type of explanation.

\subsection{REHABILITATING THE CATEGORY OF EXPLAINING THE NATURAL SCIENCES}

What is the significance of reconstructing the methodological evolution in meta-science for theology, especially fundamental theology? In the methodology of empirical science, at all stages of its development, there are very interesting intuitions that go beyond science, but also those whose roots can be found in theology. Bertrand Russell in his essay On Induction (Balashov and Rosenberg 2002, 289-294) first refers to the popular intuition related with trust to draw general conclusions based on recurring events, even though it seems that nothing guarantees their occurrence in the future.

Next, he puts forward the thesis that our reasoning is ruled by a certain uniformity of nature, which makes us perceive the recurring laws of a general characteristic. The essence of science, according to Russell, is to find and formulate such laws. We can try to reconstruct Isaac Newton's theological thinking in the following way: it is not that he can say that since he discovered gravitation, he decided that God is no longer needed, but he discovered gravity, mathematically described the relations binding physical objects, and allowed theological ideas about God, which is a justification for this and not another form of a given law, but only because a law can be formulated, and so the whole process can be rationally justified.

For theology and philosophy, particularly important is the fact of the way the original rehabilitation occurred in the history of methodology, explaining 
the role of science as well as the cause and causation included in explanatory procedures. As we know, the controversy surrounding the question "does science explain?" and the negative solutions to this problem in the context of how the natural sciences understood logical empiricism were related to the conceptual rooting of explanations in a philosophical language that spoke of a causative, purposeful cause; about substance and matter, including all of the concepts which the empiricist tradition definitely rejected. Thanks to the Aristotelian connotations, explaining matters for the empiricists became a mysterious search for causes or pointing to goals.

David-Hellel Ruben considers Mill to be the first philosopher and empiricist who conducted research on the nature of causality in the new context of the relationship between science and philosophy (Ruben 2004, 112). He ceases to explain this aura of mystery or "metaphysics" by reducing it to the concepts of the law of nature, specifically understood causality or causal law, and finally deduction. Reuben aptly points to the relationship between dependencies obtained through induction and laws in science:

\footnotetext{
In some cases, we can explain the derivative uniformities on the basis of fundamental laws alone. But in other cases, we also need initial particular information about 'the collocation of some of the primeval causes or natural agents' or the 'mode of co-existence of some of the component elements of the universe.' This information is anomic; it is a brutal fact that there is just this distribution of things in the universe, or that particular causes exist in just the number or distribution that they do" (Ruben 2004, 118).
}

Thus, the competences of physics and cosmology end with giving the initial conditions the status of the law of coexistence. According to Mill's reasoning, we can say that the concept of subtle fine-tuning in cosmology is unsustainable. In this context, Reuben asks the question: do the laws of coexistence, similar to the laws of succession, have some fundamental explanatory value? If not, then we are dealing with Mill's understanding of explanation as a causal explanation.

Therefore, a so-called final explanation of the universe is not possible in purely empiricist categories in the language that Mill or Hume propose. For theology, this conclusion is of great importance. On the one hand, it shows the important natural methodological limitation of natural science, and on the other, the chance to implement the methodological postulate of "unity" proposed by Lambert. The natural sciences are unable to validate their own assumptions. It is necessary to make a reservation that the explanation provided by theology is not competitive in relation to the explanations offered 
by natural science. If this were the case, theology would once again hear the accusation that it treats God as a category complementing the shortcomings of the empirical explanation based on the principle "God of the gaps."

Together, theology and philosophy (realistic metaphysics, epistemology with the category of truth) are able to provide an explanation in that: 1) the natural sciences do contain explanatory elements within the limits of their competences, and not just simply describe a physical reality; 2) the natural sciences explain things by referring to the existence of laws, which shows their deeply-rooted rationality (i.e. the laws of nature); 3) in the epistemology of natural science, the idea of truth appears as regulating the field of scientific studies, where on the one hand, science itself uses the so-called effective theories (containing anti-realistic elements, "useful fictions"), and on the other hand, they search for fundamental theories, and even the socalled theory for everything (putting everything that exists physically into one theory).

Let's begin to summarize our considerations with a somewhat provocative statement proposed in the context of the dispute between the natural sciences and theology. Often this debate doesn't just simply boil down to the level of theory but to the researcher who, on the one hand, practices science, while on the other hand either has or does not have religious beliefs. At times, we try to force the conviction that a believer cannot do scientific research work and be in harmony with his convictions. Yet it is at the level of individual people, not theories, that it is very easy to deal with such a thesis, for example by pointing to scholars who have significant successes in the field of physics, biology or chemistry and are also believers. Of course, there are many great scholars who do not believe in religion. So, what separates them is not their skills in physics but their worldview. The existence of many eminent scholars who are believers means that the causes of conflict must be sought elsewhere.

Certainly, it can be said that the place where the discourse on the mutual relations between theology and science takes place is not their internal methodologies, but the meta-metascientific or metamethodological levels. If the elations between the two mentioned orders are to be considered a dispute starting a debate, both sides identify with two images of the world characterized by specific ontological and epistemological assertions. The first is 
naturalism, which, generally speaking, means the belief that the universe comprises everything that exists; the ultimate being is mass / energy, while all explanations are to be of the following type: bottom-up reduction (biology into chemistry, chemistry into physics, macroscopic physics into microscopic physics) is to be the only direction of explanation. The universe, understood as everything that exists in the physical sense, does not provide us with any type of argument, let alone provide proof for the existence of God.

On the other side are various forms of theistic positions that proclaim that the universe is not everything that exists. The ultimate and necessary Being is God, not the universe. Explaining the universe must take into account both types: bottom-up and top-down, meaning the universe in its rational structure. Cognitive accessibility is to provide arguments for claims about the existence of God. At the same time, contemporary arguments for atheism continue, among others, in the subtle redefinition of faith. John Lennox, a mathematician who undertakes apologetics of theism, starting from the observation of the practices of natural science, indicates that a specific redefinition of faith is being carried out (Lennox 2009). It is based on the fact that the act of faith is identified with convictions that are not in line with the evidence. A believer's convictions are placed in a very subjective sphere. Religious revelation is, however, a historical event, supported by evidence in the strict sense, speaking in the language of natural science, and is based on empirical evidence. It is enough to quote the end of the Gospel of St. John (J 21:24-25): "This is the disciple who testifies to these things and who wrote them down. We know that his testimony is true. Jesus did many other things as well. If every one of them were written down, I suppose that even the whole world would not have room for the books that would be written."

We can also reasonably argue that in the process of creating science, in the strict sense of the natural sciences (in the sense of scientific research), implicitly accepted unscientific and clearly metaphysical assumptions are present. This is the case, for example, in the assumption that the reality of the subjects studied has an individual to species structure. If this were not the case, then every object made of iron would have to be studied from scratch, without assuming that we have credible beliefs about the properties of things made from this element. Scholars, by attributing faith only to religious phenomena, completely ignore the fact that faith and the act of faith are also fundamental things for science (also in the sense of scientific research). Let's take the simple, often boundless faith in the power of science. This can also be expressed in the way scientists are believers but in the sense that they believe in science. This is not a trivial statement. They believe in 
science, that is, they believe in its method; and if they believe in its method, they recognize it as rational, and so they believe that the world is knowable, at the same time possessing some rational property. For example, I can believe that the world can be understood in the language of mathematics.

Subsequent misunderstandings in the discussion of possible bridges and relations between theology and science are related to the ambiguity of the expression "testimony" or "proof." Part of the methodology of empirical science includes a debate on the normative status of procedures for justifying scientific claims. One of the main problems in modern scientific methodology is the question of how the scientific research method (observation, experiments, analysis of empirical data) allows us to choose between competing scientific hypotheses. How are general scientific hypotheses formulated in the first place? This issue appears in the philosophy of science as a problem with induction. Solutions to this problem are essentially presented on two levels: the inductive, where empirical data is treated as somehow supporting the hypothesis, and the deductive, where the conclusion logically follows the accepted premises.

I believe that the key to any attempts to dialogue between the methodologies of theology and the natural sciences is the broad and spacious theory of explanation, which will be meta-methodological enough to "combine" the image of the world provided by scientific and theological studies with full respect for their autonomy, limitations and competence. It is particularly important to correctly word the problem of explaining matters. God as an explanatory "category" cannot be placed in opposition to science. If God is "defined" as the one who is the natural explanation of what science is not able to explain (meaning whatever was not known till present, and the issue lies within its methodological competence), in this situation, the fact is that we have to choose between science and God.

The statements of modern apologists of the faith and theology concerning the natural sciences draw attention to the fact that theology provides a deep understanding of what science actually explains. Developing the theory of explaining based on the theology discourse with the natural sciences, exposing in this context the category of the intelligibility of creation, and above all the signatory, semiotic structure of the human and subjective reference to the world will allow for the methodological "joining" and supplementing the reductive explanation characteristic of science with a natural explanation in the opposite direction, which starts with what is simpler (a drawing, picture, word, book-explanandum) to the more complex (civilization, mind, intelligence, God-explanans). 


\section{BIBLIOGRAPHY}

ANDERWALD, Andrzej. Teologia a nauki przyrodnicze [Theology and the Natural Sciences]. Opole: Ed. Wyd. Wydziału Teologicznego Uniwersytetu Opolskiego, 2007.

Balashov, Yuri V., Alex Rosenberg. Philosophy of Science. London: Routledge, 2007.

CHMIELEwski, Adam. Filozofia Poppera [Popper's Philosophy]. Wrocław: Wydawnictwo Uniwersytetu Wrocławskiego, 1995.

HaJduk, Zygmunt. Filozofia przyrody. Filozofia przyrodoznawstwa [Philosophy of Nature. Natural Science Philosophy]. Lublin: TN KUL, 2004.

Heller, Michał. Nowa fizyka i nowa teologia. III [The New Physics and New Theology. III]. Kraków: Copernicus Center Press, 2014.

Hobson, Michael P. Bayesian Methods in Cosmology, edited by Michael P. Hobson, Andrew H. Jaffe, Andrew R. Liddle, Pia Mukherjee, David Parkinson. Cambridge: Cambridge University Press, 2010 (doi:10.1017/CBO9780511802461).

KAUCHA, Krzysztof. "Argument metafizyczny w teologii fundamentalnej” [The Metaphysical Argument in Fundamental Theology]. Ślaskie Studia Historyczno-Teologiczne 46, no 1 (2013): 52-64.

Kragh, Helge. Wielkie spekulacje. Teorie i nieudane rewolucje w fizyce i kosmologii [Great Speculations. Theories and Unsuccessful Revolutions in Physics and Cosmology]. Translated by Tomasz Lanczewski. Kraków: Copernicus Center Press, 2015.

LAMBert, Dominique. Ryzykowne spotkanie teologii z nauka [A Risky Meeting between Theology and Science]. Translated by Paloma Korycińska. Kraków: OCLC, 2018.

LEMAŃSKA, Anna. "Filozofia przyrody a teologia." In Przyrodoznawstwo-Filozofia-Teologia ["Natural Philosophy and Theology." In: Nature Studies-Philosophy—Theology], edited by Jacek Meller, Adam Świeżyński, 167-78. Warszawa: UKSW, 2010.

LENNOX, John C. God's Undertaker. Oxford: Lion Book, 2009.

ŁUkASIEWICZ, Dariusz. Opatrzność Boża, wolność, przypadek [Divine Providence, Freedom, Coincidence]. Kraków-Poznań: W drodze, 2014.

McGrath, Alister. Nauka i religia [Science and Religion]. Translated by Marek Chojnacki. Kraków: Wydawnictwo WAM, 1999.

Mutschler, Hans-Dieter. Fizyka i religia [Physics and Religion]. Translated by Józef Bremer. Kraków: Wydawnictwo WAM, 2007.

OLSZEWSKI, Adam. "Punkty styczności pomiędzy teologią a nauką." In Teologia nauki ["Meeting Points between Theology and Science." In: Theology of Sciences], edited by Janusz Mączka, Piotr Urbańczyk, 95-108. Kraków: Copernicus Center Press, 2015.

RAHner, Karl. Pisma wybrane [Selected Writings]. Translated by Grzegorz Bubel, vol. 2. Kraków: Wydawnictwo WAM, 2007.

Ratzinger, Joseph. Prawda w teologii [Truth and Theology]. Translated by Magdalena Mijalska. Kraków: Wydawnictwo M, 2001.

RuBEN, David-Hillel. Explaining Explanation. London-New York: Routledge, 2004.

RUSECKI, Marian. Wiarygodność chrześcijaństwa [Christian Credibility], vol. I. Lublin: TN KUL, 1994.

SEWERYNIAK, Henryk. "Zarys koncepcji teologii fundamentalnej" ["An Outline of Fundamental Theology's Concepts”]. Studia Ptockie (1993): 9-15. 
Swinburne, Richard. The Existence of God. Clarendon Press, 2004 (doi:10.1093/acprof:oso/ 9780199271672.001.0001).

WalCZAK, Monika. Racjonalność nauki [Scientific Rationality]. Lublin: TN KUL, 2006.

WALCZAK, Monika. "Czy możliwa jest wiedza interdyscyplinarna?" ["Is Interdisciplinary Knowledge Possible?’]. Zagadnienia Naukoznawstwa 1(207) (2016): 113-26.

WĘCŁAWski, Tomasz. "Metodologia teologii" ["Theological Methodology"]. Poznańskie Studia Teologiczne 18 (2005): 7-24.

ŻYCIŃSKI, Józef. Elementy filozofii nauki. Wydanie II [Elements of the Philosophy of Science. II Edition]. Kraków: Copernicus Center Press, 2015.

\section{Translated by Jan Kobytecki}

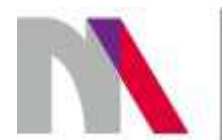

The preparation of the English version of Roczniki Teologiczne (Annals of Theology) and its publication in electronic databases was financed under contract no. 836/P-DUN/2018 from the resources of the Minister of Science and Higher Education for the popularization of science. 